\title{
Estrogen receptors involvement in intervertebral discogenic pain of the elderly women: colocalization and correlation with the expression of Substance $P$ in nucleus pulposus
}

\author{
Xiao-Xing Song ${ }^{1,2, *}$, Sheng Shi ${ }^{2,}{ }^{*}$, Zhen $\mathrm{GuO}^{3,{ }^{3}}$, Xin-Feng $\mathrm{Li}^{2}$ and Bu-Wei $\mathrm{Yu}^{1}$ \\ ${ }^{1}$ Department of Anesthesiology, Rui Jin Hospital, School of Medicine, Shanghai Jiao Tong University, Shanghai, China \\ 2 Department of Orthopaedic Surgery, Ren Ji Hospital, School of Medicine, Shanghai Jiao Tong University, Shanghai, China \\ ${ }^{3}$ Department of Orthopaedic Surgery, Yang Pu Hospital, Tongji University, Shanghai, China \\ * These authors have contributed equally to this work \\ Correspondence to: Bu-Wei Yu, email: littlestar77@126.com
}

Xin-Feng Li, email: xinfengli@126.com

Keywords: intervertebral disc, pain, estrogen receptor, nucleus pulposus, substance P, Gerotarget

Received: December 20,2016 Accepted: February 08, $2017 \quad$ Published: February 16, 2017

Copyright: Song et al. This is an open-access article distributed under the terms of the Creative Commons Attribution License (CC-BY), which permits unrestricted use, distribution, and reproduction in any medium, provided the original author and source are credited.

\section{ABSTRACT}

Estrogenic modulation of pain is an exceedingly complex phenomenon. However, whether estrogen is involved in discogenic low back pain still remains unclear. Here, immunoreactivity staining technique was used to examine the expression level of the estrogen receptors (ERa and ERß) and a pain related neuropeptide, Substance $P$ in the lumbar intervertebral discs to analyze the relationship between the ERs and Substance P. Nucleus pulposus tissues of 23 elderly female patients were harvested during spinal surgeries and made to detect the immunoreactivity staining of ERa, ER $\beta$ and Substance P. The colocalization and intensities of ERs and Substance P were explored and evaluated respectively. The correlations between changes of ERa, $E R \beta$ and Substance $P$ were also assessed. Our results revealed that Substance $P$ colocalized with ERa and ER $\beta$ both in cytoplasm and nucleus of the nucleus pulposus cells. HSCORE analysis indicated that Substance P negatively correlated with both ERa and ER $\beta$ expression. Collectively, the crosstalk between ERs and Substance P might exist in the disc tissue. Estrogen-dependent pain mechanism might partly be mediated through ERs and Substance $P$ in the nucleus pulposus of the elderly females. Estrogen and its receptors might be drug targets in discogenic low back pain diseases.

\section{INTRODUCTION}

Recently, estrogen was indicated to play an important role in pain modulation [1]. Low back pain was commonly reported after menopause and suggested to be linked to estrogen in women. However, observational studies examining exogenous estrogen's influence on back symptoms provided mixed results. Some clinical studies examining relationships between exogenous estrogen use and back pain symptoms reported a negative effect [2-4], whereas, a favorable effect [5] and no clear association [6] has also been indicated. The mechanisms by which estrogen modulates back pain appear to be highly complex.
The intervertebral disc (IVD) related pain is a significant proportion in cases of chronic back pain [7], imparting a large socioeconomic burden on the healthcare system. However, the mechanism of discogenic low back pain remains unclear $[8,9]$. Some investigations showed the involvement of estrogen on IVD health [10]. Besides, the estrogen decrease during menopause contributes to the progressive decrease of the IVD height [11]. The estrogen receptors (ERs), ER $\alpha$ and $E R \beta$, are the main mediators of estrogen action. ER $\beta$ gene expression has been detected in human IVD annulus cells [12], but the expression of $\mathrm{ER} \alpha$ and the relationship between estrogen receptors and discogenic pain have not been established.

Substance P, secreted by nerves and inflammatory cells, is a tachykinin that serves as a neurotransmitter and a 
sensory marker related to pain [13], and might be involved in the inflammation pain of several tissues [14-16]. Substance $P$ have been also described within the lumbar IVD in humans. Hence, IVD might be a pain generator [17]. Meanwhile, the influence of estrogen on the Substance P expressions in the synovium of osteoarthritis joints has been reported, which provided valuable insights into the involvement of estrogen in chronic osteoarthritis pain [18]. In this study, the relationship between the expressions of estrogen receptor and Substance P were investigated in IVD tissue.

\section{RESULTS}

\section{ERa, ERß and Substance P immunoreactivity in human nucleus pulposus}

Immunopositive staining was observed for $\mathrm{ER} \alpha$, $\mathrm{ER} \beta$ and Substance $\mathrm{P}$ protein. Cellular staining for ER and Substance $\mathrm{P}$ was identified in the native chondrocytelike cells of the nucleus pulposus tissue in IVD. Control immunohistochemistry study revealed that a brown coloration as a positive immunoreactivity of $\mathrm{ER} \alpha, \mathrm{ER} \beta$ and Substance P in the nucleus pulposus cells of the elderly men. No staining was detected when antibody was pre-incubated with a blocking peptide (Figure 1). As shown in Figure 2, both cytoplasmic and nuclear staining of $\mathrm{ER} \alpha, \mathrm{ER} \beta$ and Substance $\mathrm{P}$ immunoreactivity were observed in the nucleus pulposus cells of the female.

\section{Colocalization of Substance P with ER $\alpha$ or ER $\beta$ in human nucleus pulposus}

Dual-label confocal immunofluorescence examination was used to investigate the simultaneous expression of Substance $\mathrm{P}$ with $\mathrm{ER} \alpha$ and $\mathrm{ER} \beta$ in the nucleus pulposus. Colocalizations of Substance P (red) and ER $\alpha$ (green) or ER $\beta$ (green) were demonstrated in Figure 3. Substance P colocalized with ER $\alpha$ and ER $\beta$ at both cytoplasm and nucleus in the nucleus pulposus cells.

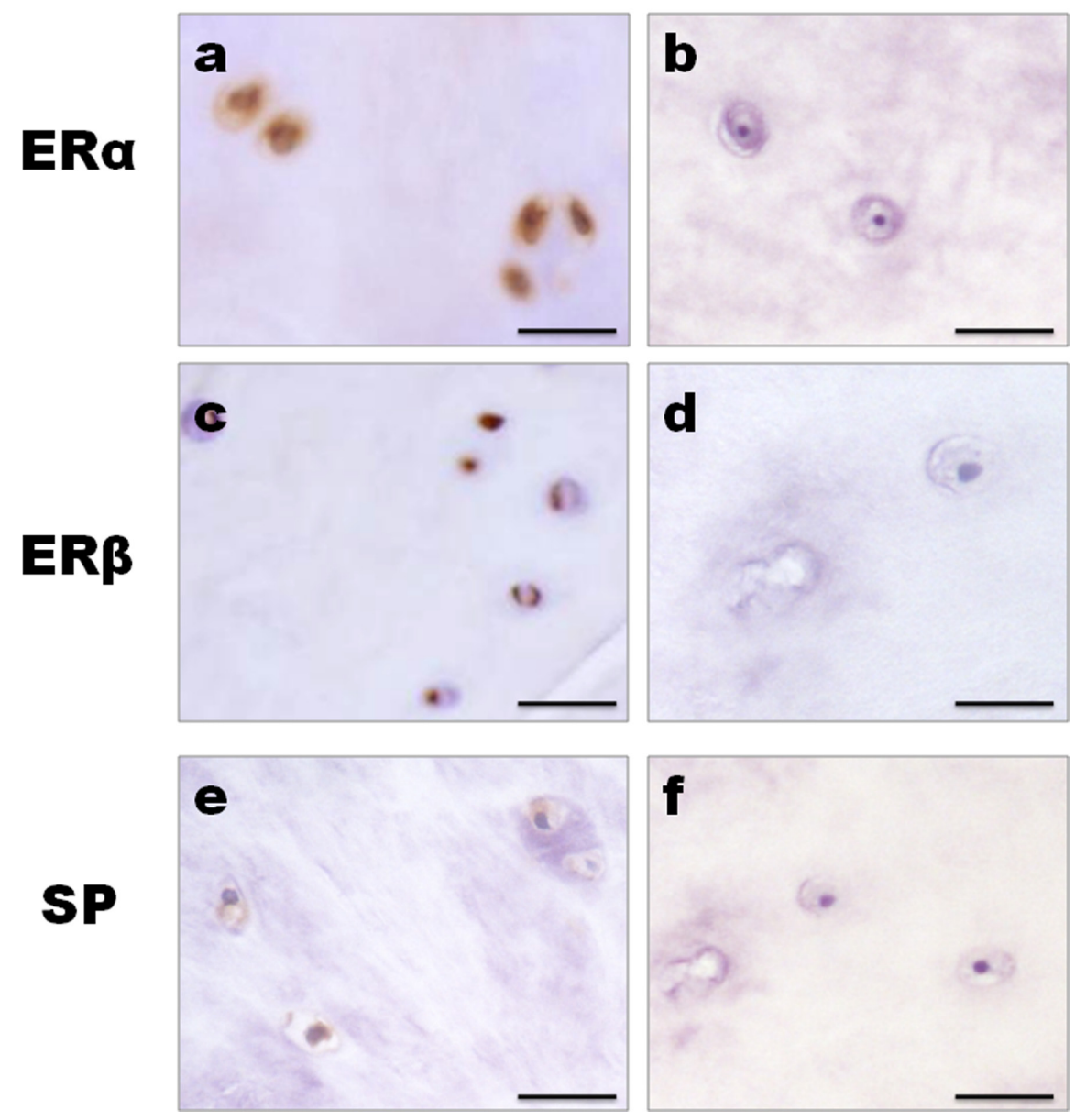

Figure 1: Control studies for immunohistochemistry. The IVD tissues of the elderly men were used as the control. Positive immunoreactivity produced a brown coloration. a., c., e. Both cytoplasmic and nuclear staining of ER $\alpha, E R \beta$ and SP immunoreactivity were observed in the nucleus pulposus cells. b., d., f. No staining could be observed when the antibody was pre-incubated with a blocking peptide. Bar represents $50 \mu \mathrm{m}$; SP, Substance P. 
Correlation analysis between changes of ERs and Substance $P$ in the nucleus pulposus

Coexpression of ERs and Substance $\mathrm{P}$ in human nucleus pulposus indicated that there might exit correlation between them. To determine the potential relationship among them, correlation analysis was performed (Figure 4). HSCORE value of Substance P staining negatively correlated with both $\mathrm{ER} \alpha(\mathrm{r}=-0.807, P<0.01$, Figure $3 \mathrm{a})$ and $\operatorname{ER} \beta(r=-0.884, P<0.01$, Figure $3 b)$ HSCORE data.

\section{DISCUSSION}

It has been reported that estrogen could influence the metabolism of the IVD and associated structures such as bone and articular cartilage [19, 20]. Much more prevalence of chronic pain conditions in women than men suggested a possible link between estrogen and pain pathogenesis [21]. However, the role of estrogen in regulating nociception remains unclear. Thus, the present study aimed to evaluate whether a possible correlation exit between ERs and Substance P in human IVD tissue. The data indicated that Substance P colocalized with both ER $\alpha$ and ER $\beta$ in the nucleus pulposus of the elderly females. HSCORE analysis showed that the change of Substance $P$ protein staining was negatively associated with that of $E R \alpha$ and $E R \beta$ protein. Estrogen might directly regulate pain in IVD through ERs. ERs were partly involved in intervertebral discogenic pain in the elderly women.

Some literature showed that menopause can accelerate IVD aging. Estrogen can prevent the
ERa

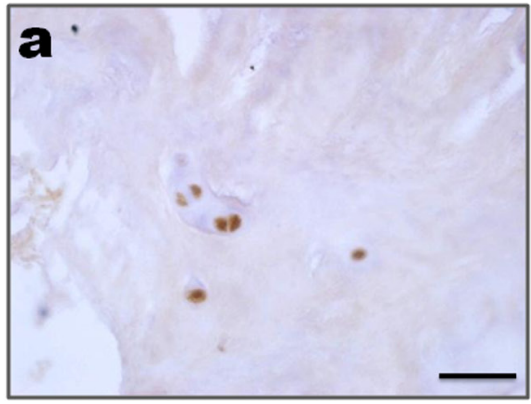

ERß

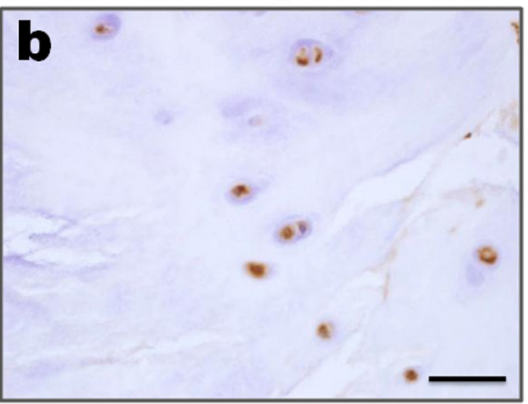

SP

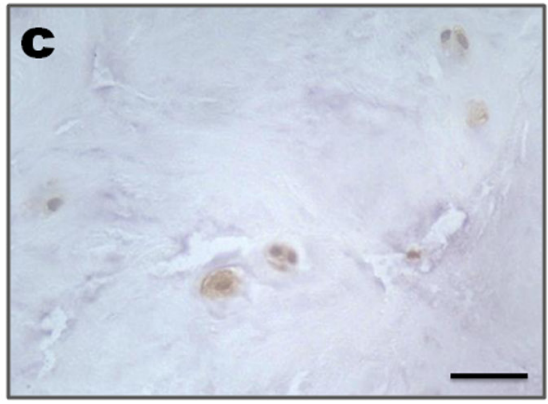

Figure 2: Expression of ER and SP in the nucleus pulposus cells. a., b. Both cytoplasmic and nuclear staining of ER $\alpha$ and ER $\beta$ immunoreactivity were observed in the nucleus pulposus cells. c. SP immunoreactivity presented with a cytoplasmic and nuclear staining. Bar represents $50 \mu \mathrm{m}$; SP, Substance P.

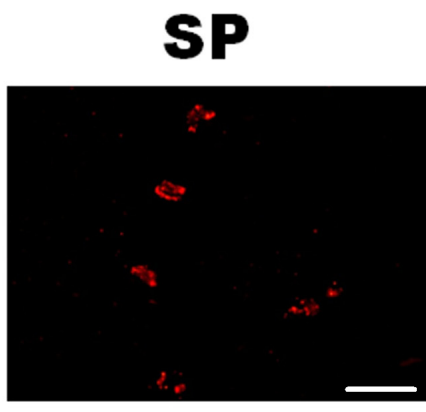

SP

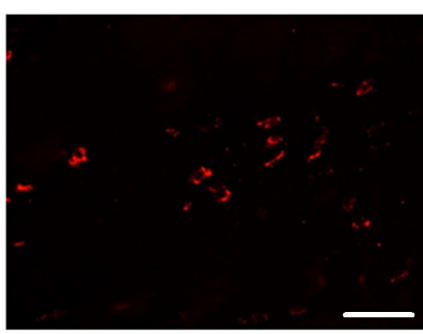

ERa

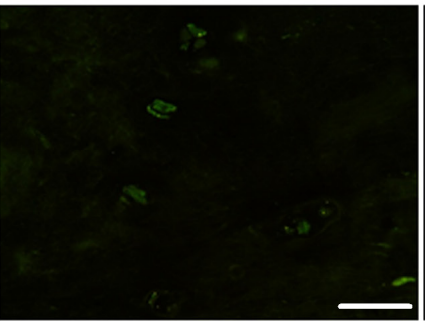

ERß

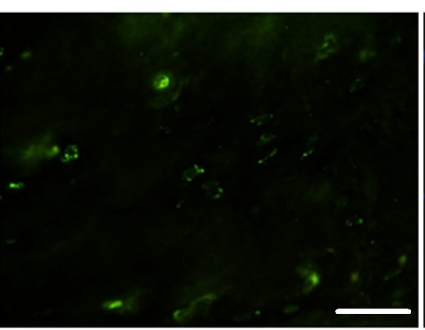

DAPI

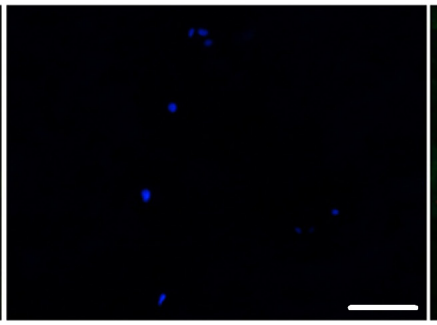

DAPI

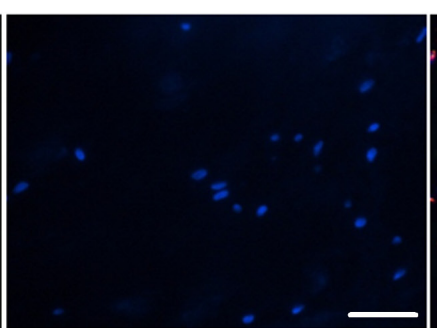

Merge

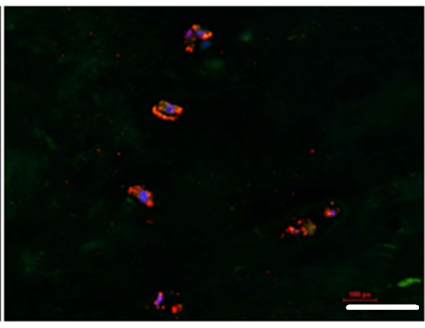

Merge

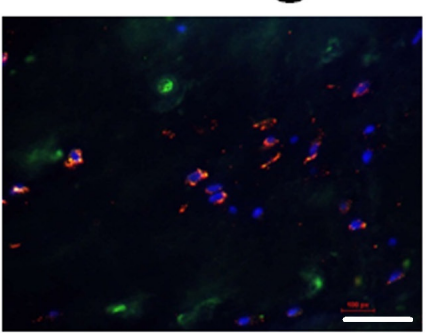

Figure 3: Simultaneous expression of SP (red) and ER $\alpha$ (green) or ERß (green) in the nucleus pulposus cells were detected under confocal microscopy. Photomicrographs showed SP colocalized with ER $\alpha$ and ER $\beta$ at the cytoplasm and nuclear in the nucleus pulposus cells. Bar represents $50 \mu \mathrm{m}$; SP, Substance P. 
degeneration and preserve the health of the IVD. Estrogen deficiency might induce disc degeneration in postmenopausal women and produce low back pain associated with disc degeneration [22]. The presentation of ER $\alpha$ and ER $\beta$ in nucleus pulposus in our study confirmed that effects of estrogen on IVD metabolism could be direct. The influence of estrogen might be cell- and site specific $[23,24]$. 17 $\beta$-estradiol increased the binding of muscimol to GABA-A-receptors in the female rat spinal cord and decreased the contents of Substance P
[25]. Estradiol could exert antinociceptive effects via an interaction with $\alpha-2$ receptors and serotonin receptors in a rat model of inflammatory hyperalgesia [26]. In studies on either ER $\alpha$ or ER $\beta$ knockout mice, the sex difference in basal mechanical pain threshold and inflammatory hypersensitivity was eliminated suggesting a fundamental role of $E R \alpha$ and ER $\beta$ in nociception in female mice [27]. Both ER $\alpha$ and $\operatorname{ER} \beta$ appeared to be involved in pain transmission and modulation but might be acting at distinct levels of the pain pathways [28]. However, the
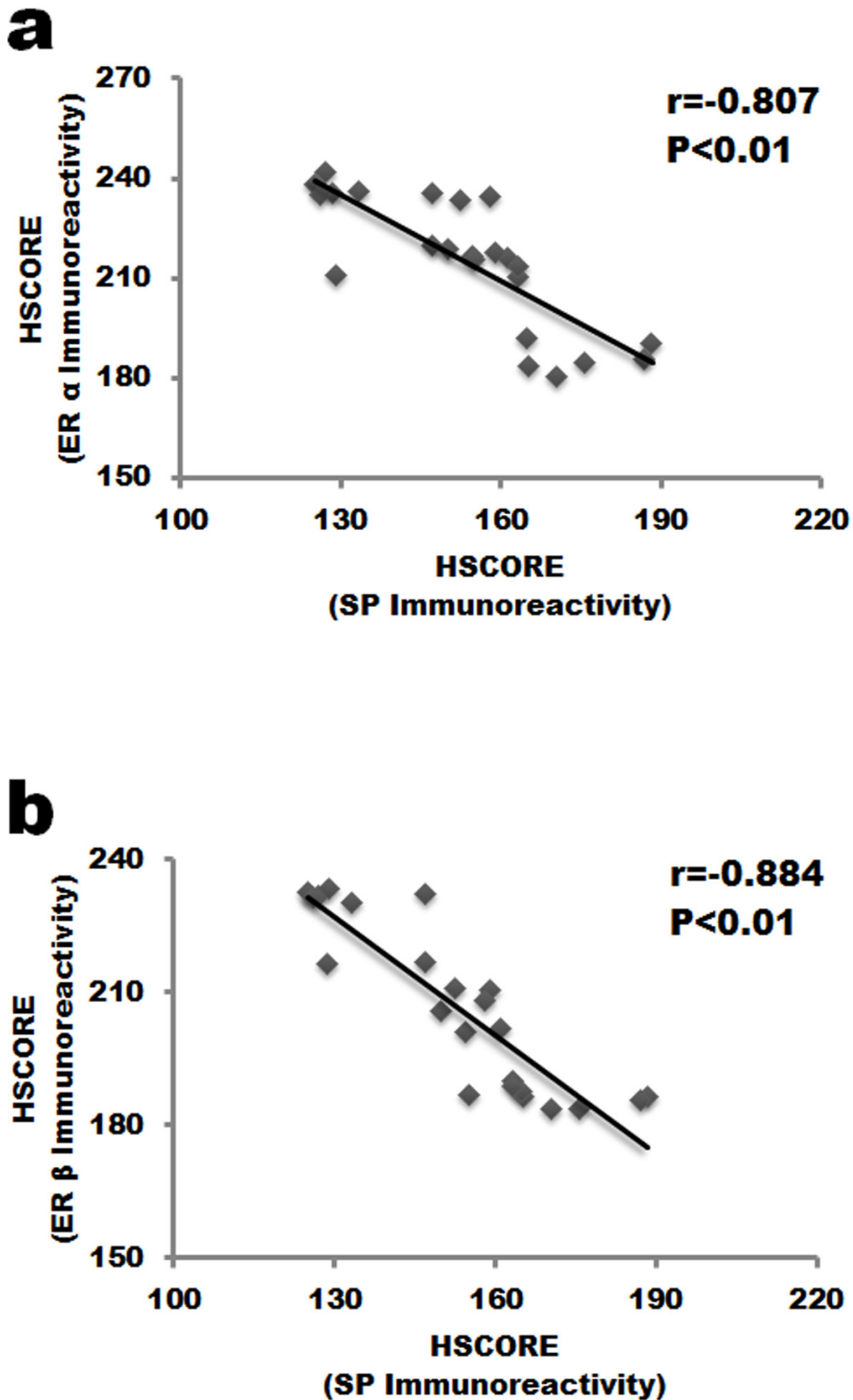

Figure 4: Correlation analysis between the expression of ERs and SP in the nucleus pulposus cells. a. ER $\alpha$ staining negatively correlated with SP expression in IVD tissue. b. SP staining was negatively associated with ER $\beta$. SP, Substance P. 
substantial contribution of estrogen to the IVD related pain remains unclear, although hormonal factors are generally associated with chronic musculoskeletal pain in women [29-34]. Osteoarthritis (OA) is also more common in women after menopause. As for female IVD, females might be more susceptible to disc degeneration than males. MR-based disc degeneration grading study of the elderly subjects demonstrated that females had more severe disc degeneration than males at all lumbar levels [35]. Clinical studies also noted that women seem to be more susceptible to the deterioration of spine [36]. A randomized, placebocontrolled, clinical trial reported that estrogen-alone use in postmenopausal women could reduce the frequency of joint pain [21]. In women with breast cancer, the arthralgia related to aromatase inhibitor therapy has been noted [37]. Our study demonstrated that Substance P was negatively associated with that of ER $\alpha$ and ER $\beta$ protein in IVD. Estrogen-dependent pain mechanism might be mediated through ERs in the nucleus pulposus of females. A novel estrogen-dependent mechanism should be studied further in chronic musculoskeletal pain, including pain generated from IVD.

Colocalization of Substance P with both ER $\alpha$ and $\mathrm{ER} \beta$ in the nucleus pulposus of females were demonstrated in our study. There might be crosstalk between Substance P and ERs. It has been reported that Substance P expression increased in the painful degenerate IVD [38]. Some study also reported that estradiol could mediate sex differences in formalin-evoked substance P release in rats [39]. In the synovium of OA joints, estrogen might partly influences intraarticular neurogenic inflammation by modulating the expressions of Substance P [18]. 17 $\beta$-estradiol could decrease the contents of Substance $\mathrm{P}$ in female rats [25]. Therefore, we speculated that estrogen might influence the expression and/or the release of Substance P through ERs in IVD. Substance P can trigger neurogenic inflammation, including vasodialtion, plasma extravasation and mast cell degranulation, thereby leading to hyperalgia [40]. The peripheral blood level of Substance P increased in women with burns [41], whiplash injury [42], femoral neck fracture [43], and complex regional pain syndrome [44]. In the synovium of OA joints, estrogen might partly influence intraarticular neurogenic inflammation by modulating the expressions of Substance P [18]. Ovarectomy could induce hyperalgesia, and treating with estrogen could counterbalance the lost of ovaries [45-47]. The present study also support an anti-nociceptive role for estrogen in pain sensitivity in IVD tissue. It has been demonstrated that exogenous estrogen therapy attenuates the hyperalgesic state in ovariectomized animals, but its mechanism should be fully clarified, especially in IVD tissue.

Several limitations should be noted in the present study. First, healthy disc tissue was not included in this study. The expression features of ER $\alpha, E R \beta$ and Substance $\mathrm{P}$ might be different between healthy and pathologic status. Second, Semiquantitative assessment of immunohistochemical results is highly subjective. Although both investigators used the same grading in our study, there also has a potential for subjective misinterpretation. Third, there was lack of pain assessment related to the findings in the present study. Therefore, future studies using a larger sample size on the $\operatorname{ER} \alpha, \operatorname{ER} \beta$ and Substance $\mathrm{P}$ expression related to pain assessment should provide more meaningful data.

In summary, ER $\alpha, E R \beta$ and Substance $P$ are expressed in human IVD tissue of the elderly woman. Substance P colocalized with both $\mathrm{ER} \alpha$ and ER $\beta$ in the nucleus pulposus of woman. Substance P expression level negatively correlated with that of both $\operatorname{ER} \alpha$ and $\operatorname{ER} \beta$. Estrogen might directly regulate pain in IVD through ERs. Estrogen-dependent pain mechanism might partly be mediated through the crosstalk between ERs and Substance P in the nucleus pulposus of the elderly females.

\section{MATERIALS AND METHODS}

\section{Patients and samples harvest}

Human IVD tissue was obtained at surgery, with informed consent of the patient or relatives. Study protocols were approved by the Institutional Review Board and the local Ethics Committee of our institution. Each subject was identified only by number. Twentythree elderly female patients(mean age: $69.3 \pm 2.6$ years; ranging 65-77 years), who underwent disc excision and/or posterior lumbar interbody fusion for lumbar disc degeneration and discogenic low back pain were selected. All women were in post-menopause status. Discography was used for diagnosis. Patients with tumor, infection, immunological and endocrine disease were excluded. All samples were obtained from L4/5 or L5/S1 levels. No multiple disc levels were used in the present study. After removing the herniated disc tissue, nucleus pulposus tissues at the center of an intervertebral disc were harvested during spinal surgeries as previously reported $[48,49]$. Cartilaginous endplates and annulus fibrosus tissues were discarded to ensure the identity of the nucleus pulposus tissue as much as possible [50-55]. The nucleus pulposus tissue was immediately washed with phosphatebuffered saline (PBS) ( $\mathrm{pH} 7.4$ ) and was routinely fixed in $4 \%$ paraformaldehyde followed by embedded in paraffin for immunostaining.

\section{Immunohistochemistry}

Immunohistochemistry was performed according to our previously described procedure $[56,57]$. Paraffin sections ( $5 \mu \mathrm{m}$ thick) of the IVD tissue were treated with xylene to remove paraffin and rehydrated in graded alcohol baths followed by three rinses with PBS. Slides were 
immunostained with the streptavidin-biotin peroxidase (SABC) technique. The IVD tissues of the elderly men were used as the control for ER $\alpha, E R \beta$ and Substance P expression. Control experiments were incubated with the antibody pre-incubated with a blocking peptide.

Antigen retrieval was performed by heating the sections in $10 \mathrm{mmol} / \mathrm{L}$ citrate buffer ( $\mathrm{pH} \mathrm{6.0)}$ ) up to 95 ${ }^{\circ} \mathrm{C}$ for $10 \mathrm{~min}$ and allowing them to cool down to room temperature for $20 \mathrm{~min}$. Then sections were incubated in $1 \% \mathrm{H} 2 \mathrm{O} 2$ for $15 \mathrm{~min}$ for blocking the endogenous peroxidase activity. After preincubation with 5\% normal goat serum (Vector, S-1000) for $30 \mathrm{~min}$ at room temperature, sections were incubated overnight at $4^{\circ} \mathrm{C}$ at room temperature with rabbit polyclonal antibody of ER $\alpha$ (Santa Cruz, sc-543, 1:100 dilution), ER $\beta$ (Abcam, ab3576, 1:100 dilution) and Substance P (Boster, BA0126, 1:100 dilution). Then sections were incubated with the corresponding biotinylated goat anti-rabbit IgG (Vector, BA-1000), applied for $30 \mathrm{~min}$ at a dilution of 1:200, followed by a triple wash in PBS. Finally, the sections were incubated in ABC complex (Vectastain ABC kit, Vector Cat\#PK-6100) for $30 \mathrm{~min}$ at room temperature. Staining was visualized with DAB peroxides substrate solution for $3 \mathrm{~min}$, followed by rinsing in distilled water briefly. The slides were dehydrated in graded ethanol, cleared in xylene, and mounted with Permount medium after counterstaining with Gill's hematoxylin solution for $3 \mathrm{~min}$.

\section{Dual label immunofluorescence staining}

Colocalization of ERs and Substance P was explored using immunofluorescence study. As we previously described [58], the slides were immersed to a boil $\left(99^{\circ} \mathrm{C} \sim 100^{\circ} \mathrm{C}\right)$ in $0.01 \mathrm{M}$ sodium citrate buffer $(\mathrm{pH} 6.0)$ for 10 minutes. After the nonspecific binding was blocked with normal 5\% goat serum (Vector, S-1000), slides were incubated overnight with a rabbit anti-Substance $\mathrm{P}$ antibody (Boster, BA0126, 1:100 dilution), followed by the Alexa Fluor ${ }^{\circledR} 594$ Goat anti-rabbit (Invitrogen, A11037) incubation $30 \mathrm{~min}$ at room temperature in dark, washed with PBS $3 * 3$ times. Then added rabbit anti-ER $\alpha$ antibody (Santa Cruz, sc-543, 1:100 dilution) incubating 30min at room temperature in dark, followed by Alexa Fluor ${ }^{\circledR}$ 488 Goat Anti-Rabbit IgG (Invitrogen, Cat:A11034) fluorescent conjugated secondary antibodies for $30 \mathrm{~min}$, washed with PBS $3 * 3$ min times. Finally, the slides were mounted with 2-(4-amidinophenyl)-6-indolecarbamidine dihydrochloride (DAPI) mounting solution $(5 \mu \mathrm{g} / \mathrm{ml})$ (Invitrogen, P36935). As for the rabbit anti-ER $\beta$ antibody (Abcam Inc., ab3576, 1:100 dilution), incubated overnight at $4{ }^{\circ} \mathrm{C}$. On the following day, the slides were washed with PBS and then incubated with Alexa Fluor ${ }^{\circledR} 488$ Goat AntiRabbit IgG 30min at room temperature, then washed with PBS and followed by DAPI staining as the same before. All sildes were evaluated by $50 \mathrm{i}$ Nikon microscope in dark. The nucleus were visualized blue using a filter 330$380 \mathrm{~nm}$ and positive labeled expression with green by filter 465-495 nm, with red by filter 530-600 nm. Control staining was performed on adjacent serial sections and consisted in replacing the primary antibody with $0.1 \%$ $\mathrm{BSA}$ in PBS.

\section{Semi-quantitative analysis of ERs and Substance $P$ staining intensities}

The intensities of $\operatorname{ER} \alpha, \operatorname{ER} \beta$ and Substance $\mathrm{P}$ immunoreactivity were semi-quantitatively evaluated using the following intensity categories: 0 , no staining; 1, weak but detectable staining; 2 , moderate or distinct staining; 3, intense staining. We normalized images background and variability in staining based on the negative control of the samples. For every sample, after summing the percentages of cells that stained at each intensity group and multiplying that by the weighted intensity of the staining, a HSCORE value was derived. The formula HSCORE $=\Sigma \mathrm{ii} \times \mathrm{Pi}$, where $\mathrm{i}$ represents the intensity scores, and $\mathrm{Pi}$ is the corresponding percentage of the cells, was used for calculation. Three tissue sections from each IVD sample were randomly obtained and five randomly selected areas were evaluated for every tissue slide under the microscope with $200 \times$ original magnification. The percentage of the cells at each intensity group within these areas was determined by two investigators blinded to the type of the IVD tissues. The average score was used.

\section{Statistical analysis}

Data from ER $\alpha, E R \beta$ and Substance $P$ immunohistochemistry scores in the IVD tissue were normally distributed as tested by Kruskal-Wallis (H) test. Quantitative data regarding HSCORE analysis are presented as mean \pm SD. The correlations between changes of ER $\alpha, E R \beta, E R \alpha / E R \beta$ and Substance P were assessed by means of Pearson's correlation coefficient test. A $P$ value of $<0.05$ was considered statistically significant. Statistical analysis was performed using the SPSS 17.0 statistical package (SPSS Inc., USA).

\section{CONFLICTS OF INTEREST}

The authors declare that they have no conflicts of interest.

\section{GRANT SUPPORT}

This study was supported by the National Natural Science Foundation of China (81400910, 81270027, 30901508). 


\section{REFERENCES}

1. Craft RM. Modulation of pain by estrogens. Pain. 2007;132 Suppl 1:S3-12.

2. Brynhildsen JO, Bjors E, Skarsgard C, Hammar ML. Is hormone replacement therapy a risk factor for low back pain among postmenopausal women? Spine (Phila $\mathrm{Pa}$ 1976). 1998;23:809-13.

3. Musgrave DS, Vogt MT, Nevitt MC, Cauley JA. Back problems among postmenopausal women taking estrogen replacement therapy: the study of osteoporotic fractures. Spine (Phila Pa 1976). 2001;26:1606-12.

4. Wijnhoven HA, de Vet HC, Smit HA, Picavet HS. Hormonal and reproductive factors are associated with chronic low back pain and chronic upper extremity pain in women - the MORGEN study. Spine (Phila Pa 1976). 2006;31:1496-502.

5. Kyllonen ES, Vaananen HK, Vanharanta JH, Heikkinen JE. Influence of estrogen-progestin treatment on back pain and disability among slim premenopausal women with low lumbar spine bone mineral density. A 2-year placebo-controlled randomized trial. Spine (Phila Pa 1976). 1999;24:704-8.

6. Papadokostakis G, Katonis P, Damilakis J, Hadjipavlou A. Does raloxifene treatment influence back pain and disability among postmenopausal women with osteoporosis? Eur Spine J. 2005; 14:977-81.

7. Freemont AJ. The cellular pathobiology of the degenerate intervertebral disc and discogenic back pain. Rheumatology (Oxford). 2009;48:5-10.

8. Hughes SP, Freemont AJ, Hukins DW, McGregor $\mathrm{AH}$, Roberts $\mathrm{S}$. The pathogenesis of degeneration of the intervertebral disc and emerging therapies in the management of back pain. J Bone Joint Surg Br. 2012;94:1298-304.

9. Peng B, Wu W, Hou S, Li P, Zhang C, Yang Y. The pathogenesis of discogenic low back pain. J Bone Joint Surg Br. 2005;87:62-7.

10. Calleja-Agius J, Muscat-Baron Y, Brincat MP. Estrogens and the intervertebral disc. Menopause Int. 2009;15:127-30.

11. Gambacciani M, Pepe A, Cappagli B, Palmieri E, Genazzani AR. The relative contributions of menopause and aging to postmenopausal reduction in intervertebral disk height. Climacteric. 2007;10:298-305.

12. Gruber HE, Yamaguchi D, Ingram J, Leslie K, Huang W, Miller TA, Hanley EN Jr. Expression and localization of estrogen receptor-beta in annulus cells of the human intervertebral disc and the mitogenic effect of 17-betaestradiol in vitro. BMC Musculoskelet Disord. 2002;3:4.

13. Harrison S, Geppetti P. Substance p. Int J Biochem Cell Biol. 2001;33:555-76

14. Ozturk N, Erin N, Tuzuner S. Changes in tissue substance $\mathrm{P}$ levels in patients with carpal tunnel syndrome. Neurosurgery. 2010;67:1655-60; discussion 60-1.
15. Hong SK, Han JS, Min SS, Hwang JM, Kim YI, Na HS, Yoon YW, Han HC. Local neurokinin-1 receptor in the knee joint contributes to the induction, but not maintenance, of arthritic pain in the rat. Neurosci Lett. 2002;322:21-4.

16. Gradl G, Finke B, Schattner S, Gierer P, Mittlmeier T, Vollmar B. Continuous intra-arterial application of substance $\mathrm{P}$ induces signs and symptoms of experimental complex regional pain syndrome (CRPS) such as edema, inflammation and mechanical pain but no thermal pain. Neuroscience. 2007;148:757-65.

17. Yamauchi K, Inoue G, Koshi T, Yamashita M, Ito T, Suzuki M, Eguchi Y, Orita S, Takaso M, Nakagawa K, Aoki Y, Ochiai N, Kishida S, et al. Nerve growth factor of cultured medium extracted from human degenerative nucleus pulposus promotes sensory nerve growth and induces substance p in vitro. Spine (Phila Pa 1976). 2009;34:2263-9.

18. Yoshida A, Morihara T, Matsuda K, Sakamoto H, Arai Y, Kida Y, Kawata M, Kubo T. Immunohistochemical analysis of the effects of estrogen on intraarticular neurogenic inflammation in a rat anterior cruciate ligament transection model of osteoarthritis. Connect Tissue Res. 2012;53:197206.

19. Li X, Phillips FM, An HS, Ellman M, Thonar EJ, Wu W, Park D, Im HJ. The action of resveratrol, a phytoestrogen found in grapes, on the intervertebral disc. Spine (Phila Pa 1976). 2008;33:2586-95.

20. Sniekers YH, Weinans H, van Osch GJ, van Leeuwen JP. Oestrogen is important for maintenance of cartilage and subchondral bone in a murine model of knee osteoarthritis. Arthritis Res Ther. 2010;12:R182.

21. Chlebowski RT, Cirillo DJ, Eaton CB, Stefanick ML, Pettinger M, Carbone LD, Johnson KC, Simon MS, Woods NF, Wactawski-Wende J. Estrogen alone and joint symptoms in the Women's Health Initiative randomized trial. Menopause. 2013;20:600-8.

22. Wang YX, Griffith JF. Menopause causes vertebral endplate degeneration and decrease in nutrient diffusion to the intervertebral discs. Med Hypotheses. 2011;77:18-20.

23. Micevych P, Eckersell CB, Holland K, Smith A. Induction of CCK mRNA levels in the limbic-hypothalamic circuit: time course and site-specific effects of estrogen. J Neurobiol. 1996;30:465-79.

24. Pajot J, Ressot C, Ngom I, Woda A. Gonadectomy induces site-specific differences in nociception in rats. Pain. 2003;104:367-73.

25. Duval P, Lenoir V, Moussaoui S, Garret C, Kerdelhue B. Substance $\mathrm{P}$ and neurokinin A variations throughout the rat estrous cycle; comparison with ovariectomized and male rats: II. Trigeminal nucleus and cervical spinal cord. J Neurosci Res. 1996;45:610-6.

26. Okuda K, Iwasaka H, Hagiwara S, Takeshima N, Takatani $J$, Uchino T, Noguchi T. The antinociceptive effects of estradiol on adjuvant-induced hyperalgesia in rats involve activation of adrenergic and serotonergic systems. J Anesth. 2011;25:392-7. 
27. Li L, Fan X, Warner M, Xu XJ, Gustafsson JA, WiesenfeldHallin Z. Ablation of estrogen receptor alpha or beta eliminates sex differences in mechanical pain threshold in normal and inflamed mice. Pain. 2009;143:37-40.

28. Coulombe MA, Spooner MF, Gaumond I, Carrier JC, Marchand S. Estrogen receptors beta and alpha have specific pro- and anti-nociceptive actions. Neuroscience. 2011;184:172-82.

29. Liu Z, Chen X, Zhou S, Liao L, Jiang R, Xu J. The histone $\mathrm{H} 3 \mathrm{~K} 9$ demethylase $\mathrm{Kdm} 3 \mathrm{~b}$ is required for somatic growth and female reproductive function. Int J Biol Sci. 2015;11:494-507.

30. Ma G, He J, Yu Y, Xu Y, Yu X, Martinez J, Lonard DM, $\mathrm{Xu}$ J. Tamoxifen inhibits ER-negative breast cancer cell invasion and metastasis by accelerating Twist1 degradation. Int J Biol Sci. 2015;11:618-28.

31. Shrestha S, Sun Y, Lufkin T, Kraus P, Or Y, Garcia YA, Guy N, Ramos P, Cox MB, Tay F, Lin VC. Tetratricopeptide repeat domain 9A negatively regulates estrogen receptor alpha activity. Int J Biol Sci. 2015;11:43447.

32. Wang N, Sun LY, Zhang SC, Wei R, Xie F, Liu J, Yan Y, Duan MJ, Sun LL, Sun YH, Niu HF, Zhang R, Ai J. MicroRNA-23a participates in estrogen deficiency induced gap junction remodeling of rats by targeting GJA1. Int J Biol Sci. 2015; 11:390-403.

33. Zou R, Zhong X, Wang C, Sun H, Wang S, Lin L, Sun S, Tong C, Luo H, Gao P, Li Y, Zhou T, Li D, et al. MDC1 Enhances Estrogen Receptor-mediated Transactivation and Contributes to Breast Cancer Suppression. Int J Biol Sci. 2015;11:992-1005.

34. Shi S, Zheng S, Li XF, Liu ZD. The Effect of Estradiol on the Growth Plate Chondrocytes of Limb and Spine from Postnatal Mice in vitro: The Role of Estrogen-Receptor and Estradiol Concentration. Int J Biol Sci. 2017;13:100-9.

35. Wang YX, Griffith JF, Ma HT, Kwok AW, Leung JC, Yeung DK, Ahuja AT, Leung PC. Relationship between gender, bone mineral density, and disc degeneration in the lumbar spine: a study in elderly subjects using an eight-level MRI-based disc degeneration grading system. Osteoporos Int. 2011;22:91-6.

36. Manson NA, Goldberg EJ, Andersson GB. Sexual dimorphism in degenerative disorders of the spine. Orthop Clin North Am. 2006;37:549-53.

37. Niravath P. Aromatase inhibitor-induced arthralgia: a review. Ann Oncol. 2013;24:1443-9.

38. Richardson SM, Doyle P, Minogue BM, Gnanalingham $\mathrm{K}$, Hoyland JA. Increased expression of matrix metalloproteinase-10, nerve growth factor and substance P in the painful degenerate intervertebral disc. Arthritis Res Ther. 2009;11:R126.

39. Nazarian A, Tenayuca JM, Almasarweh F, Armendariz A, Are D. Sex differences in formalin-evoked primary afferent release of substance P. Eur J Pain. 2014;18:39-46.
40. Dean BJ, Franklin SL, Carr AJ. The peripheral neuronal phenotype is important in the pathogenesis of painful human tendinopathy: a systematic review. Clin Orthop Relat Res. 2013;471:3036-46.

41. Onuoha GN, Alpar EK. Levels of vasodilators (SP, CGRP) and vasoconstrictor (NPY) peptides in early human burns. Eur J Clin Invest. 2001;31:253-7.

42. Alpar EK, Onuoha G, Killampalli VV, Waters R. Management of chronic pain in whiplash injury. J Bone Joint Surg Br. 2002;84:807-11.

43. Onuoha GN, Alpar EK. Elevation of plasma CGRP and SP levels in orthopedic patients with fracture neck of femur. Neuropeptides. 2000;34:116-20.

44. Schinkel C, Scherens A, Koller M, Roellecke G, Muhr G, Maier C. Systemic inflammatory mediators in posttraumatic complex regional pain syndrome (CRPS I) - longitudinal investigations and differences to control groups. Eur J Med Res. 2009;14:130-5.

45. Mannino CA, South SM, Quinones-Jenab V, Inturrisi CE. Estradiol replacement in ovariectomized rats is antihyperalgesic in the formalin test. J Pain. 2007;8:334-42.

46. Martinez-Gomez M, Cruz Y, Salas M, Hudson R, Pacheco P. Assessing pain threshold in the rat: changes with estrus and time of day. Physiol Behav. 1994;55:651-7.

47. Sanoja R, Cervero F. Estrogen modulation of ovariectomyinduced hyperalgesia in adult mice. Eur $\mathrm{J}$ Pain. 2008; 12:573-81.

48. Rodrigues LM, Oliveira LZ, Pinhal MA. Expression of heparanase isoforms in intervertebral discs classified according to Pfirrmann grading system for disc degeneration. Spine (Phila Pa 1976). 2013;38:1112-8.

49. Tsai TT, Lai PL, Liao JC, Fu TS, Niu CC, Chen LH, Lee MS, Chen WJ, Fang HC, Ho NY, Pang JH. Increased periostin gene expression in degenerative intervertebral disc cells. Spine J. 2013;13:289-98.

50. Shi S, Li XF, Liu ZD. The Effect of the Anterior Cervical Plate System on Adjacent Segments: Fact or Fiction? World Neurosurg. 2016;94:574-5.

51. Shi S, Li XF, Zhao QT, Yang LL, Liu ZD, Yuan W. Risk Factors for Dysphagia After Single-Level Anterior Cervical Decompression with Arthroplasty or Fusion: A Prospective Study Comparing 2 Zero-Profile Implants. World Neurosurg. 2016;95:148-55.

52. Shi S, Liu ZD, Li XF, Qian L, Zhong GB, Chen FJ. Comparison of plate-cage construct and stand-alone anchored spacer in the surgical treatment of three-level cervical spondylotic myelopathy: a preliminary clinical study. Spine J. 2015;15:1973-80.

53. Shi S, Liu ZD, You WJ, Ouyang YP, Li XF, Qian L, Zhong GB. Application of a stand-alone anchored spacer in noncontiguous anterior cervical arthrodesis with radiologic analysis of the intermediate segment. J Clin Neurosci. 2016;25:69-74.

54. Shi S, Liu ZD, You WJ, Ouyang YP, Li XF, Qian L, 
Zhong GB. Comparison of 2 Zero-Profile Implants in the Treatment of Single-Level Cervical Spondylotic Myelopathy: A Preliminary Clinical Study of Cervical Disc Arthroplasty versus Fusion. PLoS One. 2016;11:e0159761.

55. Shi S, Zheng S, Li XF, Yang LL, Liu ZD, Yuan W. Comparison of a Stand-Alone Anchored Spacer Versus Plate-Cage Construct in the Treatment of Two Noncontiguous Levels of Cervical Spondylosis: A Preliminary Investigation. World Neurosurg. 2016;89:28592.

56. Li XF, Wang SJ, Jiang LS, Dai LY. Gender- and regionspecific variations of estrogen receptor alpha and beta expression in the growth plate of spine and limb during development and adulthood. Histochem Cell Biol. 2012;137:79-95.

57. Song XX, Yu YJ, Li XF, Liu ZD, Yu BW, Guo Z. Estrogen receptor expression in lumbar intervertebral disc of the elderly: gender- and degeneration degree-related variations. Joint Bone Spine. 2014;81:250-3.

58. Li XF, Wang SJ, Jiang LS, Dai LY. Stage specific effect of leptin on the expressions of estrogen receptor and extracellular matrix in a model of chondrocyte differentiation. Cytokine. 2013;61:876-84. 